\title{
Recovery of Phytophthora ramorum Following Exposure to Temperature Extremes
}

\author{
Paul W. Tooley, Marsha Browning, and Dana Berner, United States Department of Agriculture-Agricultural Re- \\ search Service, Foreign Disease-Weed Science Research Unit, Ft. Detrick, MD 21702
}

\begin{abstract}
Tooley, P. W., Browning, M., and Berner, D. 2008. Recovery of Phytophthora ramorum following exposure to temperature extremes. Plant Dis. 92:431-437.

We examined the impact of exposure to high and low temperature extremes on recovery of Phytophthora ramorum both as free chlamydospores and within infected rhododendron tissue over a 7-day period. Chlamydospores held in moistened sand were incubated at 30, 35, 40, 0, -10, and $-20^{\circ} \mathrm{C}$ for up to 7 days. Infected Rhododendron 'Cunningham's White' leaf disks held in sandy loam, loam, or sand at two different soil moisture levels also were subjected to these temperatures for up to 7 days, and to a variable temperature regimen for 12 weeks. Recovery was characterized by growth of $P$. ramorum on selective agar medium following exposures to temperature treatments. Chlamydospores held in moistened sand showed a high rate of recovery at $30^{\circ} \mathrm{C}$, steadily declining recovery at $35^{\circ} \mathrm{C}$, and no recovery at $40^{\circ} \mathrm{C}$ over the 7 -day period. Chlamydospores were recovered from $0^{\circ} \mathrm{C}$ after 7 days, with little or no recovery observed at -10 or $-20^{\circ} \mathrm{C}$. In infected rhododendron tissue, P. ramorum was recovered at 20 and $30^{\circ} \mathrm{C}$ after 7 days but, at $35^{\circ} \mathrm{C}$, the pathogen showed a decline within 2 days and no recovery by 4 days. A $40^{\circ} \mathrm{C}$ treatment allowed no recovery of $P$. ramorum from infected tissue after 2 days. For cold treatments, $P$. ramorum was recovered from infected leaf disks at 0 and $-10^{\circ} \mathrm{C}$ after 7 days. At $-20^{\circ} \mathrm{C}$, recovery declined rapidly after 1 to 3 days and no recovery was obtained after 4 days. $P$. ramorum showed nearly $100 \%$ recovery from leaf disks subjected to a 12 -week variable temperature treatment based on ambient summer temperatures in Lewisburg, TN. The results suggest that $P$. ramorum is capable of surviving some highly adverse temperature conditions for at least 7 days both as free chlamydospores in sand and within infected host tissue. Thus, $P$. ramorum present as free chlamydospores or within tissue of infected plants shipped to the eastern United States has the potential to survive some of the adverse conditions encountered in summer and winter in many eastern states.
\end{abstract}

Phytophthora ramorum Werres, De Cock \& Man in 't Veld, a recent introduction into the United States, has proven to be a threat to hardwood forests on the west coast, specifically tanoak (Lithocarpus densiflorus (Hook \& Arn.) Rehder) and Quercus spp. (34). This pathogen has a broad host range which is ever-expanding and includes understory plants and commonly grown nursery plants $(19,25)$. Some native eastern plants in the Ericaceous family such as mountain laurel, blueberry, bearberry, and huckleberry are susceptible to infection by $P$. ramorum (43), as well as white oak, chestnut oak, and northern red oak that developed disease following stem inoculations (42). This raises concerns for the health of the hardwood forests in the eastern United States should P. ramorum become introduced.

Attempts have been made to determine the risk posed by $P$. ramorum to the eastern

Corresponding author: P. W. Tooley

E-mail: paul.tooley@ars.usda.gov

Accepted for publication 18 October 2007.

doi:10.1094/PDIS-92-3-0431

This article is in the public domain and not copyrightable. It may be freely reprinted with customary crediting of the source. The American Phytopathological Society, 2008.
United States using weather data $(39,45)$. However, the utility of efforts to determine the risk of $P$. ramorum spread is restricted by our limited knowledge of the pathogen's survival ability. Previous work has shown that temperatures supporting mycelial growth of $P$. ramorum in vitro were 2 to $28^{\circ} \mathrm{C}$, chlamydospore production 8 to $28^{\circ} \mathrm{C}$, and sporangia production 10 to $30^{\circ} \mathrm{C}$ $(12,47)$. In spite of the wide temperature range for growth shown by $P$. ramorum, harsh winter temperatures encountered in the northern regions of the country may limit its establishment.

Because $P$. ramorum is primarily a foliar pathogen, it is likely to overwinter as hyphae or chlamydospores in stems and leaves on the plant or in abscised leaves found on the soil surface, in leaf litter, or in shallow depths of soil. Therefore, the fungus will be subjected to freezing ambient temperatures, freeze and thaw fluctuations, and desiccation. Similarly, high temperatures and dry conditions encountered in the summers in various regions may limit growth and establishment of $P$. ramorum.

Davidson et al. (8) reported that $P$. ramorum survived the warm, dry summer months in California in attached bay laurel (Umbellularia californica) leaves, although levels declined over time. These workers were not able to reisolate $P$. ramorum from abscised leaves collected from leaf litter. Davidson et al (10) also established a strong link between sporulation on bay laurel and transmission of $P$. ramorum in California forest ecosystems. It was demonstrated (9) that $P$. ramorum chlamydospores could survive a 30-day treatment at $15^{\circ} \mathrm{C}$ in water or on moist filter paper, but did not survive when initially dried at room temperature and $30 \%$ relative humidity for $30 \mathrm{~min}$. Studies by other workers $(5,13,29,37,38)$ have demonstrated that $P$. ramorum chlamydospores are long-lived and can be recovered following placement in potting media after many months. Knowledge of the impact of extreme temperatures on $P$. ramorum survival both as chlamydospores and within host tissue is necessary to predict the ability of the pathogen to overwinter and provide inoculum for continuing epidemics in forest ecosystems. Such knowledge also would help identify constraints to oversummering and overwintering survival, and allow predictions of how widely the pathogen may become established in new regions. This information would be of use to regulators, inspectors, and Forest Service personnel who seek to determine the limits to $P$. ramorum establishment.

We assessed the germinability of $P$. ramorum chlamydospores following exposure to extreme constant temperatures, both high and low, for up to 7 days. We also assessed the recovery of $P$. ramorum from plant host tissue (Rhododendron 'Cunningham's White') at extreme constant temperatures for up to 7 days. Leaf disks were incubated in three different soils (sand, sandy loam, and loam) and at two different water holding capacities (WHCs) in each soil type. In addition, we monitored recovery of $P$. ramorum in plant host tissue held under previously mentioned soil and moisture regimes, but subjected to ambient temperatures based on historical weather data for a period of 12 weeks.

\section{MATERIALS AND METHODS}

$P$. ramorum was cultured on $20 \%$ V8 media, unless otherwise noted, and maintained at $20^{\circ} \mathrm{C}$. Pimaricin-ampicillinrifampicin-pentachloronitrobenzene-hymexazol (PARPH) $(24,31)$ with $4 \%$ clarified V8 juice added was used for chlamydospore germination and leaf tissue isolations. Pr-52 was the isolate used in these studies, and originated from Rhododendron spp. in California in 2000. This is a well-characterized isolate belonging to the 
US-1 genotype $(22,23)$ that has been used in many previous studies $(12,17,18,20,21$, $30,35,41,43)$.

Chlamydospores. Sand inoculum was produced using the procedure described by Graham (15) and used by Colburn and Shishkoff (6). Mycelial plugs of $P$. ramorum were used to inoculate $250-\mathrm{ml}$, canted-neck polystyrene tissue culture flasks (BD Biosciences, Bedford, MA) containing $40 \mathrm{ml}$ of $20 \%$ clarified V8 juice broth. The flasks were incubated at $20^{\circ} \mathrm{C}$ in darkness for 14 days, at which time the V8 broth was replaced with $100 \mathrm{ml}$ of sterile distilled water. Cultures then were incubated for two additional weeks, at which time contents were filtered through cheesecloth. The resulting hyphae and spores were added to autoclaved, air-dried then pre-moistened (5\% vol/wt) sand (Play Sand; Quikrete Inc., Atlanta) held in Ziploc bags at a ratio of 10 cultures to 1 liter of sand. The sand inoculum was mixed vigorously by hand for 5 min every other day for 7 days and then stored at $20^{\circ} \mathrm{C}$ in darkness for at least 1 month. Chlamydospore germination levels on PARPH+ V8, determined for each batch of inoculum produced, ranged from 40 to $47 \%$. We saw no colonies originating from hyphal fragments. We also could readily observe germ tubes coming directly out of the chlamydospores, assuring that they did not originate from attached hyphal fragments. Chlamydospores were exposed to temperatures of $30,35,40,0,-10$, and $-20^{\circ} \mathrm{C}$ in separate experiments. Samples of sand inoculum $\left(5 \mathrm{~cm}^{3}\right.$ each) were placed in 15 $\mathrm{ml}$ conical plastic centrifuge tubes and incubated at the above temperatures for 1 , $2,3,4$, and 7 days in replicates of three. A duplicate set of samples was incubated at $20^{\circ} \mathrm{C}$ as a control. Following incubation, the contents of each tube were transferred to $125-\mathrm{ml}$ polypropylene Erlenmeyer flasks containing $45 \mathrm{ml}$ of sterile $0.2 \%$ water agar. The flasks were capped with

Table 1. Weekly temperatures used in 12-week variable temperature growth chamber experiments assessing survival of Phytophthora ramorum in Rhododendron 'Cunningham's White' leaf disks ${ }^{\mathrm{a}}$

\begin{tabular}{lcc}
\hline & \multicolumn{2}{c}{ Temperature $\left({ }^{\circ} \mathbf{C}\right)$} \\
\cline { 2 - 3 } Week & Minimum & Maximum \\
\hline 1 & 16 & 29 \\
2 & 17 & 31 \\
3 & 17 & 31 \\
4 & 18 & 31 \\
5 & 19 & 32 \\
6 & 18 & 32 \\
7 & 19 & 33 \\
8 & 19 & 32 \\
9 & 18 & 32 \\
10 & 17 & 32 \\
11 & 17 & 32 \\
12 & 17 & 32 \\
\hline
\end{tabular}

${ }^{a}$ Based on average ambient summer temperatures (June to August) found in Lewisburg, TN for the period 1982 to 2001 (32). plastic caps and shaken by hand to disperse chlamydospores, and 1-ml aliquots were delivered to each of three 9-cmdiameter petri plates of PARPH+V8. Numbers of colonies resulting from germinated chlamydospores were counted under a dissecting microscope over a period of up to 14 days. Experiments were performed three times and data analyzed by analysis of variance using PROC GLM in the SAS statistical package (36).

Leaf disks, constant temperatures. Leaves were collected from Rhododendron 'Cunningham's White' plants maintained in a greenhouse, and surface disinfested for 1 to $2 \mathrm{~min}$ in $1 \%$ sodium hypochlorite followed by four rinses in distilled water. Ziploc bags containing 1,000 leaf disks $\left(0.32-\mathrm{cm}^{2}\right.$ disks removed using a hole punch) were inoculated by immersion in $300 \mathrm{ml}$ of a sporangia suspension $(3,000$ sporangia/ml) produced by incubating colony plugs in $1 \%$ (sterile) soil extract for 72 h. After 5 days, the sporangia suspension was replaced with distilled water and the $20^{\circ} \mathrm{C}$ incubation was continued for 4 weeks. The presence of chlamydospores within uncleared leaf tissue was confirmed microscopically prior to use in trials.

Infected leaf disks were incubated in two locally collected soils and in sand (Play Sand; Quikrete Inc.). The sandy loam soil (66\% sand, $24 \%$ silt, $10 \%$ clay; $\mathrm{pH} 3.7 ; 6.6 \%$ organic matter $[\mathrm{OM}]$ ) was collected from a hardwood forest near Frederick, MD. The loam soil (37\% sand, $39 \%$ silt, $24 \%$ clay; $\mathrm{pH} 5.3 ; 1.4 \%$ OM) was collected from a cultivated field at Ft. Detrick, MD used in agricultural research for over 20 years. Soils were air dried and passed through a 2-mm sieve; sand was rinsed and air dried prior to use. Scintillation vials $(20 \mathrm{ml})$ were filled with $10 \mathrm{~cm}^{3}$ of soil or sand. Distilled water was added to adjust moisture levels to 30 and $60 \%$ WHC and vial contents were stirred. Equivalent volumetric soil moistures were 0.068 and $0.138 \mathrm{~cm}^{3}$ water $\mathrm{g}^{-1}$ soil., respectively, for sand; 0.394 and $0.750 \mathrm{~cm}^{3}$ for sandy loam; and 0.204 and $0.391 \mathrm{~cm}^{3}$ water $\mathrm{g}^{-1}$ soil for loam. Three infected leaf disks were added to each vial. Samples were incubated for $1,2,3,4$, and 7 days at $30,35,40,0,-10$, or $-20^{\circ} \mathrm{C}$. A $20^{\circ} \mathrm{C}$ control was included with each of the three runs. Leaf disks were removed from vials following incubation, rinsed, quartered, and plated on PARPH+V8. Plates were examined periodically for up to 14 days. Recovery was characterized as growth of $P$. ramorum from any one of four sections of each leaf disk into the media. Experiments were performed three times.

Data were analyzed by logistic regression modeling the odds of growth (binary response, growth or no growth) on any of the three disks in a vial. The analyses were conducted using the logistic procedure (PROC LOGISTIC) of the SAS statistical package (36) with logit values (natural log of the odds of growth) as the dependent variable, soil type and WHC as class variables, and temperature and days of incubation as covariates. After the first set of analyses, WHC was dropped from the models (see Results) and the data were reanalyzed with temperature within soil types and days of incubation within soil types as covariates. Single-degree-offreedom contrasts were written to compare logit values of each soil type at each temperature and days of incubation and to compare slopes between soil types attributable to temperatures and days of incubation.

Leaf disks, variable high temperatures. We examined historical weather records for selected regions of the country where conditions appear to be conducive to infection by $P$. ramorum. Ambient and soil temperature data was acquired from the National Climatic Data Canter, Asheville, NC (http://www.ncdc.noaa.gov) (32). Lewisburg, TN was chosen because it is representative of regions under high risk of establishment of sudden oak death in the eastern United States $(39,45)$. Temperatures at Lewisburg, TN (Table 1) were found to be intermediate between those for Raleigh, NC and Columbia, SC.

Infected Rhododendron 'Cunningham's White' leaf disks in sand, sandy loam, and loam at 30 and $60 \%$ WHC were incubated at temperatures representative of average diurnal ambient temperature in Lewisburg, TN from June through August (19822001). Temperatures were adjusted on a weekly basis to correspond with historical minimum and maximum means (Table 1). Six plastic containers (2 liters, 19 by 19 cm; Rubbermaid Home Products, Wooster, $\mathrm{OH})$ were filled with $1,500 \mathrm{~cm}^{3}$ of sand, sandy loam, or soil, for a total of 18 containers. Distilled water was added to achieve 30 and $60 \%$ WHC. Thirty-six nylon mesh bags containing five infected leaf disks were buried in each container of soil or sand. One container filled with each soil-moisture combination was placed in each of three incubators and arranged randomly. Two incubators were programmed to ramp from the mean minimum to the mean maximum temperature over a $24-\mathrm{h}$ period without lights. The third incubator was maintained at a constant $20^{\circ} \mathrm{C}$ as a control. Containers were weighed and moisture levels adjusted back to beginning levels two times a week. Seven weeks into the experiment, covers were placed loosely on top of containers to counteract uneven drying due to variable fan speed within incubators.

To sample, three mesh bags containing five leaf disks each were removed from each container once a week. Leaf disks were agitated in distilled water to dislodge soil particles, blotted, cut in four segments, and plated on PARPH-V8 media. Any leaf disks which appeared dry were rehydrated in distilled water for an hour prior to plat- 
ing. Plates were examined periodically for up to 14 days. Recovery was characterized as growth of $P$. ramorum from any one of four sections of each leaf disk into the media. Leaf disks contained an average of 45 chlamydospores internally (based on 40 leaf disks examined), with many more chlamydospores visible on the leaf surface.

\section{RESULTS}

Growth of chlamydospores at constant high and low temperatures. For the high-temperature treatments, chlamydospores showed the highest colony numbers at 20 and $30^{\circ} \mathrm{C}$, declining recovery at $35^{\circ} \mathrm{C}$ over the 7-day period, and no recovery at $40^{\circ} \mathrm{C}$ (Fig. 1A). After an exposure period of 1 day, recovery from the 30 and $35^{\circ} \mathrm{C}$ treatments was slightly but significantly reduced compared with the $20^{\circ} \mathrm{C}$ control treatment, while the $40^{\circ} \mathrm{C}$ treatment differed significantly (via the Waller-Duncan $\mathrm{K}$ ratio $t$ test, $k=100$ ) from the other three treatments, showing nearly zero recovery (Fig. 1A). At days 2 and 4, the 20 and $30^{\circ} \mathrm{C}$ treatments did not differ significantly from one another, whereas they did at days 3 and 7. High recovery rates were observed at these two temperatures throughout the 7-day period, ranging from 254 to 320 colonies per plate for the $20^{\circ} \mathrm{C}$ treatment and 217 to 299 colonies per plate for the $30^{\circ} \mathrm{C}$ treatment. A significant difference was not observed between the 30 and $35^{\circ} \mathrm{C}$ treatments at day 1 , but it was at days $2,3,4$, and 7 , with recovery of chlamydospores at $35^{\circ} \mathrm{C}$ exhibiting a steady decline over time, from a mean of 281 colonies per plate at day 1 to 0 colonies per plate at day 7 . Recovery at $35^{\circ} \mathrm{C}$ was significantly higher than that at $40^{\circ} \mathrm{C}$ at days $1,2,3$, and 4; however, at day 7 , both showed no recovery.

For low-temperature treatments, we observed chlamydospore-based colony numbers ranging from 163 to 285 colonies at $20^{\circ} \mathrm{C}$ and from 142 to 172 colonies at $0^{\circ} \mathrm{C}$ (Fig. 1B). Little or no recovery was observed at -10 or $-20^{\circ} \mathrm{C}$ (Fig. 1B). The $0^{\circ} \mathrm{C}$ treatment showed significantly lower chlamydospore growth compared with the $20^{\circ} \mathrm{C}$ control treatment at days $1,2,3$, and 7, but not at day 4 (Fig. 1B). The -10 and $-20^{\circ} \mathrm{C}$ treatments never differed significantly from one another throughout, with a range of one to nine colonies observed at $-10^{\circ} \mathrm{C}$ over 1 to 7 days and no colonies for the $-20^{\circ}$ treatment at all days.

Recovery from infected leaf disks at constant high and low temperatures. Leaf disks, high temperatures. P. ramorum showed nearly $100 \%$ recovery at 20 and $30^{\circ} \mathrm{C}$ over all 7 days; however, at $35^{\circ} \mathrm{C}$, recovery showed a decline within 2 days (Fig. 2). By day 4, there was no recovery from the $35^{\circ} \mathrm{C}$ treatment in any of the three soils (Fig. 2). A temperature of $40^{\circ} \mathrm{C}$ was lethal to $P$. ramorum after 2 days and no growth was observed in any treatment at 3 , 4 , or 7 days. No significant differences in recovery were observed between 30 and $60 \%$ WHC at any time period; therefore, data for the two WHC levels were combined for subsequent analyses. Slope values for temperature within soil types were negative and significant for each soil type, indicating that chances for pathogen regrowth decreased as temperature increased to $40^{\circ} \mathrm{C}$. Slope values for days of incubation within soil types were negative and significant for each soil type, indicating that chances for pathogen regrowth decreased as days of incubation increased. Based on logit values, the slope for recovery from loam soil declined significantly more sharply than did the slope for recovery from sandy loam soil. But at 20,30, and $35^{\circ} \mathrm{C}$ with incubation for 1 or 2 days, the logit values from loam were significantly greater than logit values from sandy loam. At 20 and $30^{\circ} \mathrm{C}$ for 3 and 4 days, incubation the logits for loam also were significantly greater than the logits for sandy loam. These results indicate that there were better chances of recovery in loam than sandy loam under these conditions but chances of recovery diminished more quickly with increasing temperature in loam. There were no significant differences between either of the two soil types and sand.
Leaf disks, low temperatures. P. ramorum was recovered at high rates from infected Rhododendron 'Cunningham's White' leaf disks at temperatures of 20, 0, and $-10^{\circ} \mathrm{C}$ for up to 7 days buried in sand, loam, and sandy loam soils (Fig. 3). However, at $-20^{\circ} \mathrm{C}$, recovery declined rapidly after 1 to 3 days and no recovery was obtained in any of the treatments tested after 4 or 7 days. As observed for hightemperature treatments, no significant differences were observed between 30 and $60 \% \mathrm{WHC}$ at any of the time periods tested; therefore, data were combined for subsequent analyses. Slope values for temperature within soil types were positive and significant for each soil type, indicating that chances for pathogen regrowth increased as temperature increased to $20^{\circ} \mathrm{C}$. Slope values for days of incubation within soil types were negative and significant for each soil type, indicating that chances for pathogen regrowth decreased as days of incubation increased. At $-20^{\circ} \mathrm{C}$, incubation in sand for 1,2 , or 3 days gave significantly higher logit values than incubation in loam for the same amount of time, indicating better chances of recovery in sand under these conditions. No other differences between soil types were de-

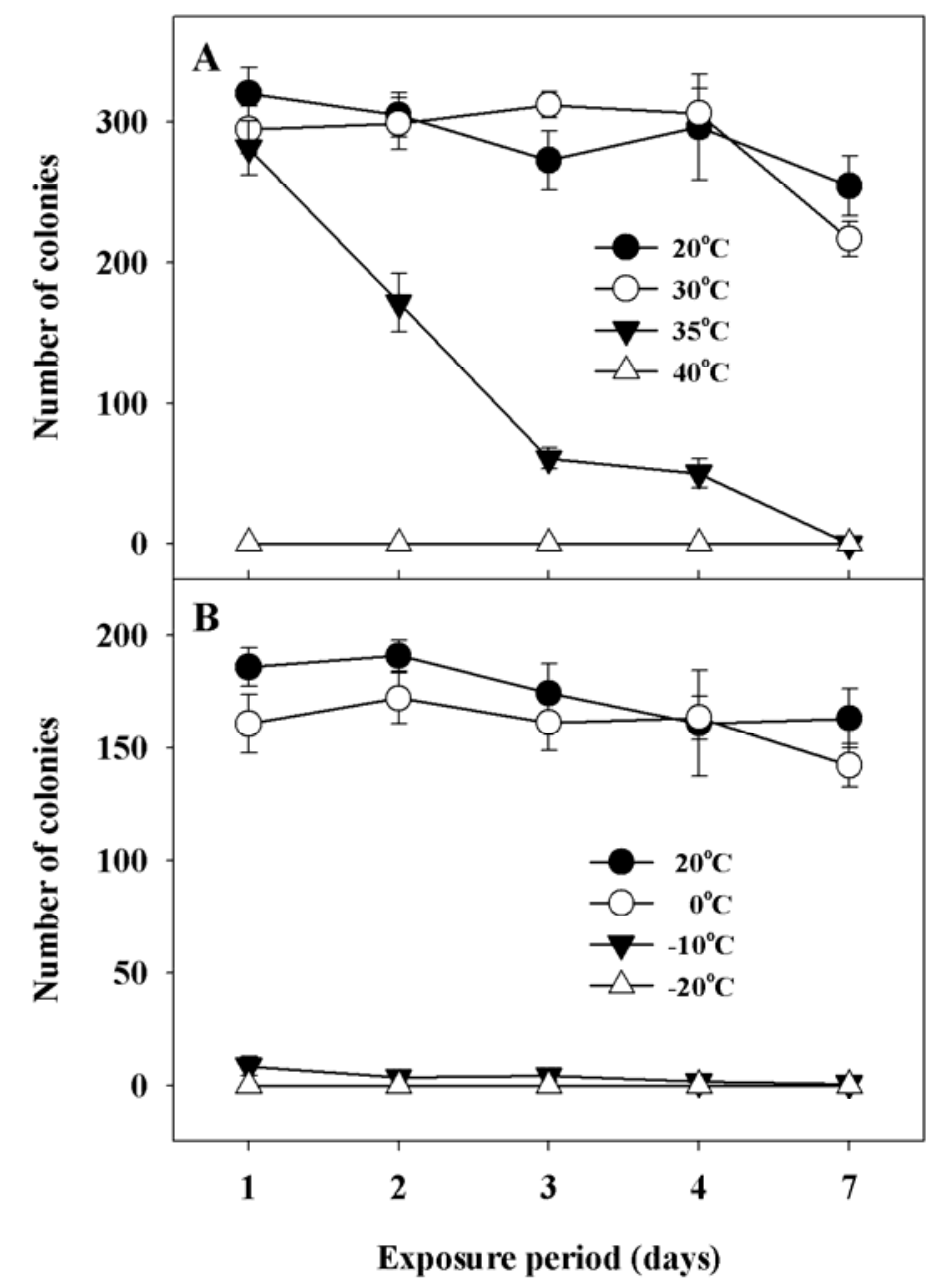

Fig. 1. Recovery of chlamydospores of Phytophthora ramorum under A, high- and $\mathbf{B}$, low-temperature treatments. Error bars represent standard deviation. 
tected. No differences in slopes attributable to temperature or days of incubation were detected among soil types.

Recovery from leaf disks at variable temperatures. Recovery of $P$. ramorum from infected Rhododendron 'Cunningham's White' leaf disks was at or near $100 \%$ for all treatments over the 12 weeks of both experiments. Treatment differences were not observed for soil type or WHC.

\section{DISCUSSION}

The results of our experiments show that $P$. ramorum is able to withstand temperatures of $35^{\circ} \mathrm{C}$ for up to 4 days as free chlamydospores in sand and $40^{\circ} \mathrm{C}$ for 1 to 2 days within infected Rhododendron 'Cunningham's White' leaf disks. The presence of abundant chlamydospores within infected leaf disks was confirmed microscopically, leading us to conclude that chlamydospores were the primary means of survival in leaf disks .

Several previous studies have been performed to investigate survival of $P$. ramorum in soil and infected plant tissue. Linderman and Davis (29) found that $P$. ramorum could be detected in soil held at $20^{\circ} \mathrm{C}$ in darkness via baiting and direct plating for up to 6 months following infestation with sporangia, and for up to 12 months following infestation with chlamydospores. Shishkoff (37) found that $P$. ramorum as mycelium or embedded in leaf tissue and buried in soil under greenhouse conditions (approximately $25^{\circ} \mathrm{C}$ ) could be recovered after 654 days. In terms of heat tolerance of $P$. ramorum, Swain et al. (41) reported that treatments of $24 \mathrm{~h}$ at $40^{\circ} \mathrm{C}, 2$ $\mathrm{h}$ at $45^{\circ} \mathrm{C}$, and $1 \mathrm{~h}$ at $55^{\circ} \mathrm{C}$ were sufficient to kill 1-cm-diameter $P$. ramorum colonies growing on $5 \% \mathrm{~V} 8$ juice agar.

Our observations of infected rhododendron tissue are similar in that we both report $40^{\circ} \mathrm{C}$ as a critical temperature for survival, although we found that a longer incubation period $(48 \mathrm{~h})$ was required to eliminate recovery from infected rhododendron leaf disks. Swain et al. (41) also studied the effect of composting and heat treatment on infected plant material (artificially and naturally infected Quercus agrifolia wood chips, artificially inoculated $Q$. agrifolia stem sections, and artificially infected bay laurel leaves) and found that 2 weeks of oven exposure at $55^{\circ} \mathrm{C}$ prevented recovery of $P$. ramorum from these substrates. However, lower temperatures and shorter intervals at a $55^{\circ} \mathrm{C}$ treatment of plant substrates were not examined in this study, leaving undetermined whether they would have affected recovery.

Harnik et al. (17) reported a $60 \%$ recovery rate for $P$. ramorum from artificially infected bay laurel leaves following a $55^{\circ} \mathrm{C}$ exposure for 1 week, whereas a 2-week treatment at this temperature eliminated recovery of the pathogen. We observed no recovery from infected rhododendron leaf disks exposed to $40 \mathrm{C}$ for 2 days. The difference in our findings could be due to several factors, including differences in inoculation and recovery strategies, incubation methods, the type of plant tissue assayed, and the isolates used in the experiments. In the Harnik et al. study, leaves were infected by wound inoculating bay laurel leaves with an agar slurry of $P$. ramorum. After 10 days of incubation in a sealed container, leaves were subjected to heat treatment. We observed microscopically that substantial numbers of chlamydospores did not form until 2 to 3 weeks after inoculation of rhododendron leaves with sporangia; therefore, we allowed the incubation to continue for 4 weeks. Thus, chlamydospore quantity and age likely
$30 \%$ Water holding capacity

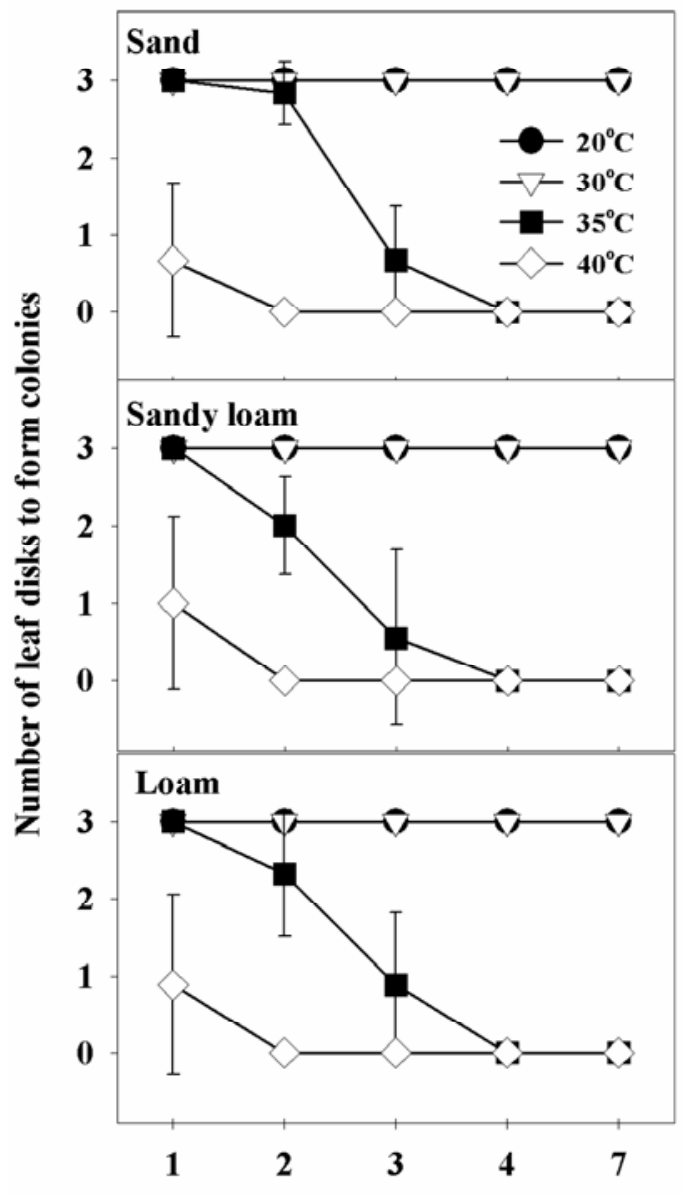

Exposure period (days)
$60 \%$ Water holding capacity

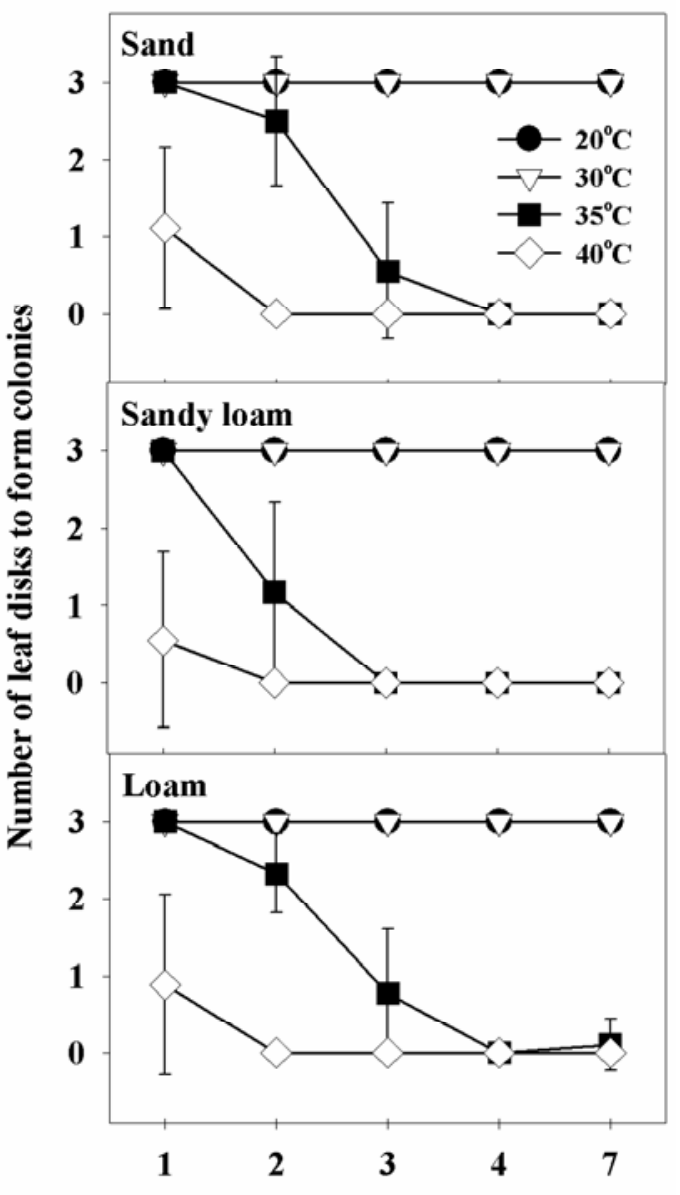

Exposure period (days)

Fig. 2. Results of high-temperature treatments for infected rhododendron leaf disks buried in three different soils at two water holding capacities for 1, 2, 3, 4, and 7 days. Error bars represent standard deviation. 
would have varied between our work and that of Harnik et al. (17). Furthermore, they incubated leaves in a moist chamber for $48 \mathrm{~h}$ at room temperature to enhance the success of recovery of the pathogen prior to plating on selective medium. Fichner et al. (13) reported that hydration for 3 weeks enhanced recovery of $P$. ramorum from rhododendron leaf disks buried in mesh bags in forest soils. Thus, hydration treatment may activate some chlamydospores to germinate that would not have germinated immediately upon direct plating. In addition, Harnik et al. (17) examined plates for growth of $P$. ramorum from bay leaves over an 8-week period compared with only 2 weeks in our study. We were not able to incubate and read plates for longer than 2 weeks due to growth of Pythium spp. from the nonsterile soil used in our experiments. Another difference between the two studies is in the plant material used. Bay laurel leaves are much less succulent compared with rhododendron leaves and may offer the pathogen greater protection from extremes of temperature. Finally, isolate differences might also partially account for differences in results among the various studies. A short- coming of the current study is that we used only a single isolate of the pathogen (Pr$52)$, even though the isolate is well characterized $(12,17,18,20-23,30,41,43)$. Swain et al. (41) utilized five isolates (Pr-1, Pr-2, Pr-5, Pr-52, and Pr-102) to assess survival of $P$. ramorum cultures, and a mixture of isolates Pr-52 and Pr-102 to inoculate bay laurel leaves. Harnik et al. (17) used isolates Pr-1, Pr-2, and Pr-5 to inoculate bay laurel leaves that were subjected to a $55^{\circ} \mathrm{C}$ treatment. Additional isolates should be tested to see if their survival at extreme temperatures varies from what we observed with isolate Pr-52. Future studies also should be performed with additional plant substrates and temperature treatments, including infected bay laurel leaves placed at a range of temperatures, to fully determine the parameters governing hightemperature survival of $P$. ramorum in host tissue.

For other Phytophthora spp. subjected to heat treatment, chlamydospores and hyphae of $P$. cinnamomi and a lowtemperature isolate of $P$. megasperma were killed in moist soil and infected walnut twigs within $20 \mathrm{~min}$ at $45^{\circ} \mathrm{C} \mathrm{(26).} \mathrm{How-}$ ever, $30 \mathrm{~min}$ were required at $45^{\circ} \mathrm{C}$ to kill all propagules of $P$. cactorum. Propagules of a high-temperature isolate of $P$. megasperma were still viable after $30 \mathrm{~min}$ at $45^{\circ} \mathrm{C}$ (26). Coelho et al. (4) reported that temperatures of $47^{\circ} \mathrm{C}$ for several hours were necessary for populations of $P$. nicotianae chlamydospores to decline to undetectable levels. Enclosure in host tissue may provide chlamydospores some protection from high temperatures and dry conditions. For example, $P$. infestans, normally killed at temperatures $>30^{\circ} \mathrm{C}$, has been shown to survive in stem tissue exposed to $40^{\circ} \mathrm{C}$ (27).

Under the variable warm temperatures we tested (Table 1), which represent ambient temperatures in Lewisburg, $\mathrm{TN}$ from June to August, we found close to $100 \%$ recovery of $P$. ramorum from leaf disks held in sand or soil, indicating that this set of treatments was not sufficient to reduce survival of the pathogen significantly. We also did not observe any difference in recovery levels between 30 and $60 \%$ WHC for any of the temperatures or time periods tested. We would expect that incubation in drier soils than tested here would have a detrimental impact on survival of $P$. ramorum. In fact, because $P$. ramorum

\section{$30 \%$ Water holding capacity}

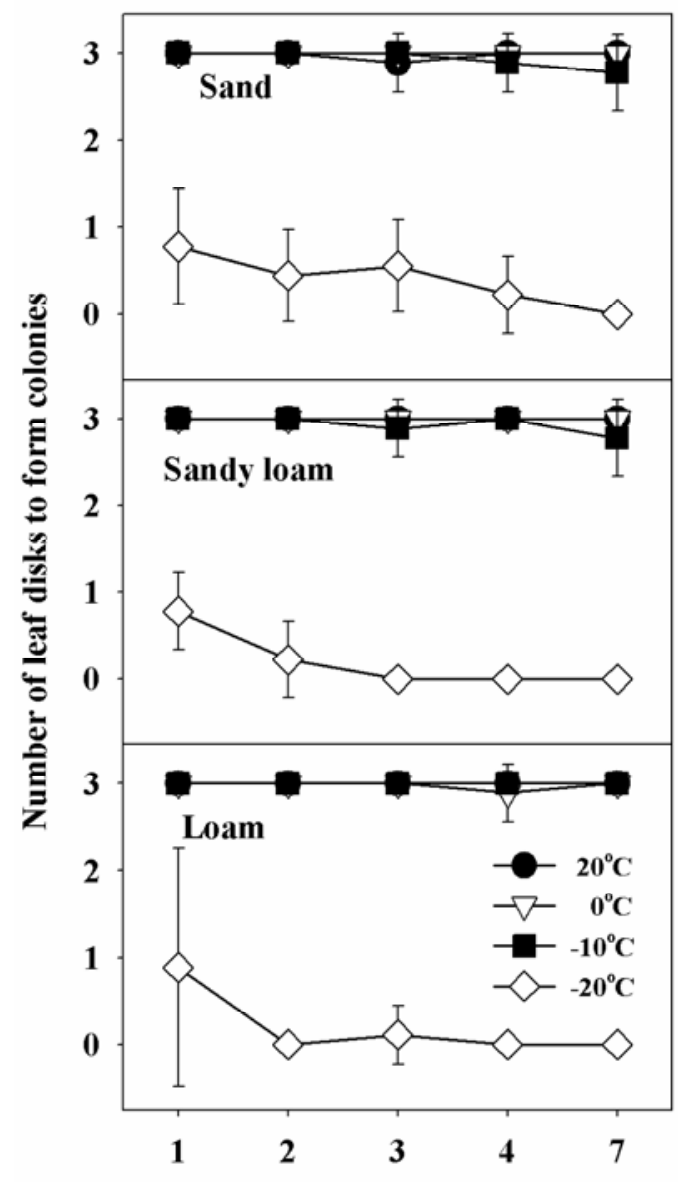

Exposure period (days)
$60 \%$ Water holding capacity

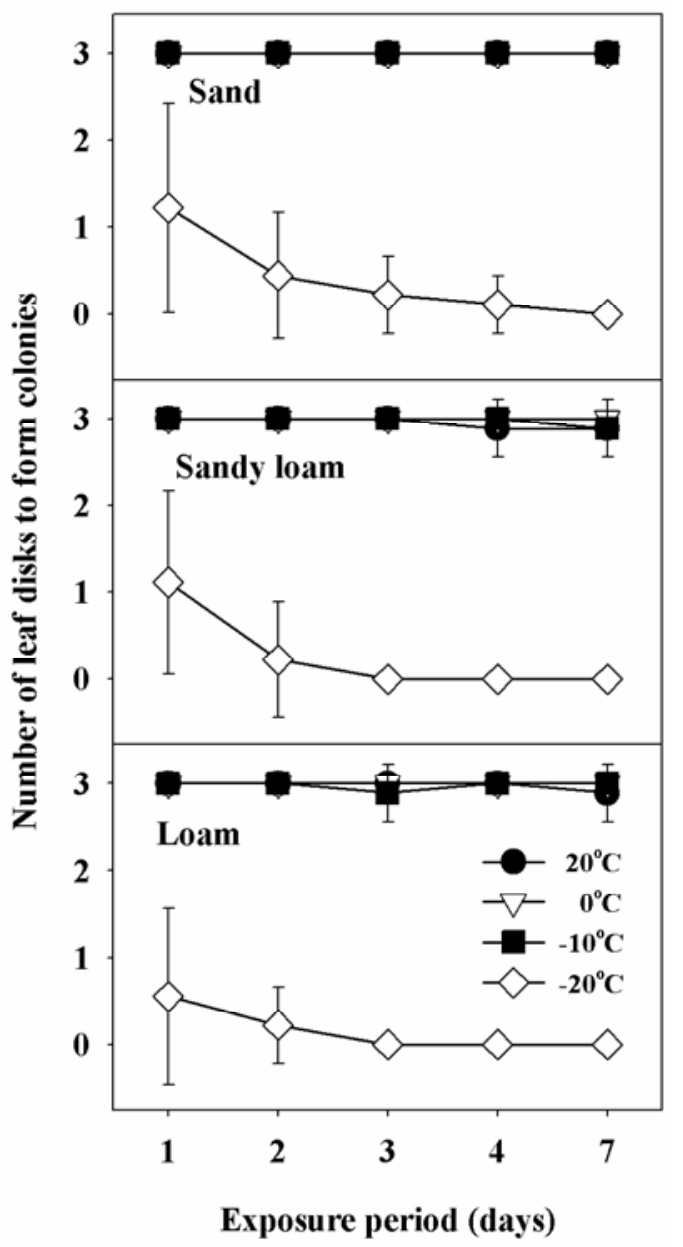

Fig. 3. Results of low-temperature treatments for infected rhododendron leaf disks buried in three different soils at two water holding capacities for $1,2,3$, 4 , and 7 days. Error bars represent standard deviation. 
appears to be able to tolerate the warm temperatures found in temperate regions, soil moisture may have a larger impact in limiting its establishment in a particular area. More stringent sets of variable temperature parameters need to be tested to determine the effects of fluctuating temperatures and soil moistures as typically occur in nature on survival.

It is not uncommon for various species of Phytophthora to overwinter in infected host tissue $(1,7,14,16,28,48)$. We found that $P$. ramorum within infected rhododendron leaf disks showed nearly $100 \%$ recovery at 0 and $-10^{\circ} \mathrm{C}$ for up to 7 days in sand, loam, and sandy loam soils. In contrast, incubation of free chlamydospores at $-10^{\circ} \mathrm{C}$ for up to 7 days resulted in little to no recovery. A sharp drop in survival of $P$. ramorum in leaf disks occurred at $-20^{\circ} \mathrm{C}$, although even at this temperature the pathogen survived in all three soils for up to several days. From these results, we surmise that the threshold for survival of $P$. ramorum in rhododendron tissue under these time periods is between -10 and $-20^{\circ} \mathrm{C}$, and between 0 and $-10^{\circ} \mathrm{C}$ for free chlamydospores. Ambient mean minimum values in parts of the northeastern United States over a 20 -year period were as low as $-11^{\circ} \mathrm{C}$ in Newton, NJ and $-18^{\circ} \mathrm{C}$ in Caribou, ME. Mean soil temperatures measured at a depth of $10.2 \mathrm{~cm}$ declined to 0 and $-5^{\circ} \mathrm{C}$, respectively.

In terms of the ability of other Phytophthora spp. to survive cold temperatures, De Bruyn (11) reported that pure cultures of $P$. infestans could survive up to 10 days at $-17^{\circ} \mathrm{C}$ and up to 5 days at $-25^{\circ} \mathrm{C}$. Dry conditions enhanced survival, and manure was a more favorable substrate than was soil or sand. Benson (1) observed that inactivation of $P$. cinnamomi in cornmeal agar disks occurred by 2,6 , or 16 days of exposure to $-6.7,-3.8$, and $-1.4^{\circ} \mathrm{C}$, respectively. Chlamydospores in soil were found to be inactivated at about the same rate as mycelium in agar. For $P$. lateralis in $\mathrm{OM}$ in soil, no reduction in survival for 20 weeks was noted at 5,10 , or $15^{\circ} \mathrm{C}$; however, at $-5^{\circ} \mathrm{C}$, a significant decrease in survival occurred within 2 weeks. However, $P$. lateralis was still detected in frozen $\mathrm{OM}$ after 16 weeks (33). $P$. parasitica survived in leaf disks exposed to $-4.5^{\circ} \mathrm{C}$ for several days only, and less than 11 days at $0^{\circ} \mathrm{C}(28)$. P. parasitica also failed to survive in leaf disks placed on the soil surface of pots held outdoors, presumably from both cold temperatures and desiccation. Sneh and McIntosh (40) found that sporangia and oospores of $P$. cactorum retained viability in soil held for several hours at $-10^{\circ} \mathrm{C}$. Thus, our results indicate that $P$. ramorum is very robust in its ability to survive at cold temperatures when compared with other species.

To help predict the temperature limitations that may affect growth and establishment of $P$. ramorum, we identified the ranges of temperature and exposure periods which prevent recovery of this pathogen, both from within infected host tissue and as free chlamydospores in sand. In comparison with other Phytophthora spp., $P$. ramorum shows a strong capacity to withstand both excessively hot and cold temperatures. Based on these results, $P$. ramorum likely should be able to overwinter in many parts of the eastern United States in rhododendron host tissue or as free chlamydospores, and also withstand summer conditions in many parts of the eastern United States. In spite of its apparent ability to survive temperatures characteristic of summer and winter in the eastern United States, there have been no reports yet of $P$. ramorum becoming established in this region in spite of the many nursery finds made in $2006(44,46)$. Conversely, in the United Kingdom, $P$. ramorum has been observed to infect oak trees in a natural setting, in close proximity to other infected plant species $(2,3)$. Thus, the potential for $P$. ramorum to move from ornamental hosts to oak in a natural setting has been proven. Thus, a better understanding of the conditions under which $P$. ramorum may survive in host tissue leads to greater understanding of its potential to cause epidemics on valued forest species in diverse ecosystems.

\section{LITERATURE CITED}

1. Benson, D. M. 1982. Cold inactivation of Phytophthora cinnamomi. Phytopathology 72:560-563.

2. Brasier, C., Denman, S., Webber, J., and Brown, A. 2006. Sudden oak death: recent developments on trees in Europe. Proc. Sudden Oak Death Second Sci. Symp.: The State of our Knowledge. U. S. For. Serv. Gen. Tech. Rep. PSW-GTR-196.

3. Brasier, C. M., Denman, S., Brown, A. V., and Webber, J. F. 2004. Sudden oak death (Phytophthora ramorum) discovered on trees in Europe. Mycol. Res. 108:1108-1110.

4. Coelho, L., Mitchell, D. J., and Chellimi, D. O. 2000. Thermal inactivation of Phytophthora nicotianae. Phytopathology 90:1089-1097.

5. Colburn, G., Sechler, K., and Shishkoff, N. 2005. Survivability and pathogenicity of Phytophthora ramorum chlamydospores in soil. (Abstr.) Phytopathology 95:S20.

6. Colburn, G. C., and Shishkoff, N. 2006. Density of Phytophthora ramorum chlamydospores in soil necessary to cause infection. (Abstr.) Phytopathology 96:S25.

7. Crosier, W. 1934. Studies in the biology of Phytophthora infestans (Mont.) De Bary. N. Y. (Cornell) Agric. Exp. Stn. Memo. 155:1-40.

8. Davidson, J. M., Maloney, P. E., Wickland, A. C., Morse, A. C., Ejensen, C., and Rizzo, D. M. 2002. Phytophthora ramorum and sudden oak death in California: transmission of Phytophthora ramorum via Umbellularia californica (California bay) leaves in California oak woodlands. Sudden Oak Death Science Symposium, Monterey, CA.

9. Davidson, J. M., Rizzo, D. M., Garbelotto, M., Tjosvold, S., and Slaughter, G. W. 2002b. Phytophthora ramorum and sudden oak death in California: II. Transmission and Survival. In: Proc. Fifth Symp. Oak Woodlands: Oaks in California's Changing Landscape, San Diego, CA. Gen Tech Rep PSW-GTR-184. R. B. Standiford, D. McCreary, and K. L. Purcell, technical coordinators. Pacific Southwest Research Station, Forest Service, United States Department of Agriculture, Albany, CA.

10. Davidson, J. M., Wickland, A. C., Patterson, H., Falk, K., and Rizzo, D. M. 2005. Transmission of Phytophthora ramorum in mixedevergreen forests in California. Phytopathology 95:587-596.

11. DeBruyn, H. L. G. 1926. The overwintering of Phytophthora infestans (Mont.) De By. Phytopathology 16:121-138.

12. Englander, L., Browning, M., and Tooley, P. W. 2006. Growth and sporulation of Phytophthora ramorum in vitro in response to temperature and light. Mycologia 98:365-373.

13. Fichtner, E., Lynch, S., and Rizzo, D. 2005. Seasonal survival of Phytophthora ramorum in soils. (Abstr.) Phytopathology 95:S29.

14. Gerlach, W. W. P., Hoitink, H. A. J., and Schmitthenner, A. F. 1976. Survival and host range of Phytophthora citrophthora in Ohio nurseries. Phytopathology 66:309-311.

15. Graham J. H. 1990. Evaluation of tolerance of citrus rootstocks to Phytophthora root rot in chlamydospore-infested soil. Plant Dis. 74:743-746.

16. Grove, G. G., Ellis, M. A., Madden, L. V., and Schmitthenner, A. F. 1985. Overwinter survival of Phytophthora cactorum in infected strawberry fruit. Plant Dis. 69:514-515.

17. Harnik, T. V., Mejia-Chang, M., Lewis, J., and Garbelotto, M. 2004. Efficacy of heat-based treatments in eliminating the recovery of the sudden oak death pathogen (Phytophthora ramorum) from infected California bay laurel leaves. HortScience 39:1677-1680.

18. Hayden, K., Ivors, K., Wilkinson, C., and Garbelotto, M. 2006. TaqMan chemistry for Phytophthora ramorum detection and quantification, with a comparison of diagnostic methods. Phytopathology 96:846-854.

19. Henricot, B., and Prior, C. 2004. Phytophthora ramorum, the cause of sudden oak death or ramorum leaf blight and dieback. Mycologist 18:151-156.

20. Huberli, D., Van Saint-Glass, W., Tse, J. G., and Garbelotto, M. 2003. First report of foliar infection of starflower by Phytophthora ramorum. Plant Dis. 87:599.

21. Huberli, D., Wilkinson, C., Smith, M. A., Meshriy, M., Harnik, T. Y., and Garbelotto, M 2006. Pittosporum undulatum is a potential Australian host of Phytophthora ramorum. Australas. Plant Dis. Notes 1:19-21.

22. Ivors, K., Gargelotto, M., Vries, I. D. E., Ruyter-Spira, C., Hekkert, T. E., Rosenzweig, N., and Bonants, P. 2006. Microsatellite markers identify three lineages of Phytophthora ramorum in U.S. nurseries, yet single lineages in U.S. forest and European nursery populations. Mol. Ecol. 15:1493-1505.

23. Ivors, K. L., Hayden, K. J., Bonants, J. M., Rizzo, D. M., and Garbelotto, M. 2004. AFLP and phylogenetic analyses of North American and European populations of Phytophthora ramorum. Mycol. Res. 108:378-392.

24. Jeffers, S. N., and Martin, S. B. 1986. Comparison of two media selective for Phy tophthora and Pythium spp. Plant Dis. 70:1083-1043.

25. Jones J. 2005. APHIS list of plants regulated and associated with Phytophthora ramorum. On-line publication. USDA-APHIS

26. Juarez-Palacios, C., Felix-Gastelum, R., Wakeman, R. J., Paplomatas, E. J., and DeVay, J. E. 1991. Thermal sensitivity of three species of Phytophthora and the effect of soil solarization on their survival. Plant Dis. 75:1160-1168.

27. Kable, P. F., and Mackenzie, D. R. 1980. Survival of Phytophthora infestans in potato stem lesions at high temperatures and implications for disease forecasting. Plant Dis. 64:165-167.

28. Kuske, C. R., and Benson, D. M. 1983. Overwintering and survival of Phytophthora para- 
sitica, causing dieback of Rhododendron. Phytopathology 73:1192-1196.

29. Linderman, R. G., and Davis, E. A. 2006. Survival of Phytophthora ramorum compared to other species of Phytophthora in potting media components, compost, and soil. HortTechnology 16:502-507.

30. Meshriy, M., Huberli, D., Harnik, T., Miles, L., Reuther, K., and Garbelotto, M. 2006. Variation in susceptibility of Umbellularia californica (Bay Laurel) to Phytophthora ramorum. Pages 87-89 in: Proc. Sudden Oak Death Second Sci. Symp.: The State of our Knowledge, Monterey, CA. S. J. Frankel, P. J. Shea, and I. M. Haverty, eds. Gen Tech Rep. PSW-GTR196. Pacific Southwest Research Station, Forest Service, Unites States Department of Agriculture, Albany, CA.

31. Mitchell, D. J. and Kannwischer-Mitchell, M. E. 1992. Phytophthora. Pages 31-38 in: Methods for Research on Soilborne Phytopathogenic Fungi. L. L. Singleton, J. D. Milhail, and C. M. Rush, eds. American Phytopathological Society Press, St. Paul, MN.

32. National Climatic Data Center. 2002. Cooperative Summary of the Day, TD3200. Asheville, $\mathrm{NC}$

33. Ostrofsky, W. D., Pratt, R. G., and Roth, L. F. 1977. Detection of Phytophthora lateralis in soil organic matter and factors that affect its survival. Phytopathology 67:79-84.

34. Rizzo, D. M., Garbelotto, M., Davidson, J. M., Slaughter, G. W., and Koike, S. T. 2002. Phy- tophthora ramorum as the cause of extensive mortality of Quercus spp. and Lithocarpus densiflorus in California. Plant Dis. 86:205-214.

35. Rizzo, D. M., Garbelotto, M., Davidson, J. M., Slaughter, G. W., and Koike, S. T. 2002. Phytophthora ramorum and sudden oak death in California: I. Host relationships. Pages 733740 in: 5th Symp. California Oak Woodlands. R. Standiford and D. McCreary, eds. U. S. For. Serv. Gen. Tech. Rep. PSW-GTR-184.

36. SAS Institute, Inc. 2004. SAS/STAT 9.1 User's Guide. SAS Institute, Inc., Cary, NC.

37. Shishkoff, 2007. Persistence of Phytophthora ramorum in soil mix and roots of nursery ornamentals. Plant Dis. 91:1245-1249.

38. Shiskoff, N., and Tooley., P. W. 2004. Persistence of Phytophthora ramorum in nursery plants and soil. (Abstr.) Phytopathology 94:S95.

39. Smith, W. D., Couston, J. W., Goheen, E. M., Sapio, F., Gottschalk, K. W., Frankel, S. J., Dunn, P., and Tkacz, B. M. 2002. Development of a national survey protocol for detection of Phytophthora ramorum. Proc. Sudden Oak Death Sci. Symp. Monterey, CA.

40. Sneh, B., and McIntosh, D. L. 1974. Studies on the behavior and survival of Phytophthora cactorum in soil. Can. J. Bot. 52:795-802.

41. Swain, S., Harnick, T., Mejia-Chang, M., Hayden, K., Bakx. W., Creque, J., and Garbelotto, M. 2006. Composting is an effective treatment option for sanitization of Phytophthora ramorum-infected plant material. J.
Appl. Microbiol. 101:815-827.

42. Tooley, P. W., and Kyde, K. L. 2006. Susceptibility of some eastern forest species to Phy tophthora ramorum. Plant Dis. 91:435-438.

43. Tooley, P. W., Kyde, K. L., and Englander, L. 2004. Susceptibility of selected Ericaceous ornamental host species to Phytophthora ramorum. Plant Dis. 88:993-999.

44. USDA Animal Plant Health Inspection Service. 2006. Phytophthora ramorum. Pest Detection and Management Programs. Online publication.

45. Venette, R. C., and Cohen, S. D. 2006. Potential climatic suitability for establishment of Phytophthora ramorum within the contiguous United States. For. Ecol. Manage. 231:18-26

46. Wamishe, Y. A., Jeffers, S. N., and Hwang, J 2006. Phytophthora ramorum and other species of Phytophthora detected in field soil and water at retail nurseries in the southeastern USA. (Abstr.) Phytopathology 96:S120.

47. Werres, S., Marwitz, R., Man In'T Veld, W., De Cock, Arthur W. A. M., Bonants, P. J. M. De Weerdt, M., Themann, K., Ilieva, E., and Baayen, R. P. 2001. Phytophthora ramorum sp. nov., a new pathogen on Rhododendron and Viburnum. Mycol. Res. 105:1155-1165.

48. Weste, G. 1983. Population dynamics and survival of Phytophthora. Pages 237-257 in: Phytophthora: Its Biology, Taxonomy, Ecology, and Pathology. D. C. Erwin, S. BartnickiGarcia, and P. H. Tsao, eds. American Phytopathological Society, St. Paul, MN. 